
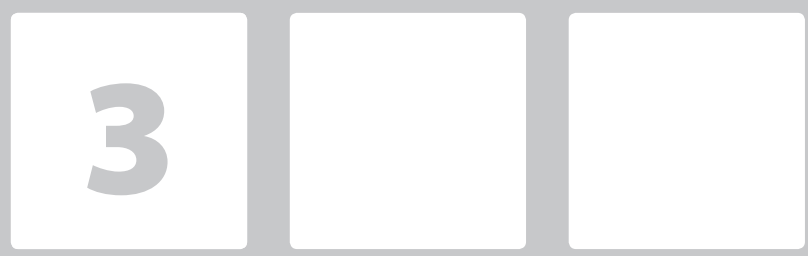

\title{
HIGHER EDUCATION AND SUSTAINABILITY: UNDERSTANDING OF THE MANAGERS OF A HIGHER EDUCATION INSTITUTION
}

\section{Educação superior e sustentabilidade: entendimentos dos gestores de uma instituição de ensino superior}

\section{Nelson Santos Machado}

Dr. em Eng. de Produção pela UFSC. Prof. e Pesq. da Univer. do Oeste de Santa Catarina (Unoesc) no Mestrado Profis. em Adm. Unoesc. Chapecó, SC. Brasil. e-mail: nelson.machado@unoesc.edu.br

\section{Josiane Weber}

Mestre em Adm. pela UNOESC. Técnica da Univ. Federal da Fronteira Sul (UFFS). Chapecó, SC. Brasil.e-mail:josiweber@yahoo.com.br

\section{Amélia Silveira}

Pós-Dr em Ciências de La Inform. pela Univer. Complutense de Madrid, Espanha. Profa. aposentada pela Univ. Federal de Santa Catarina. Florianópolis, SC. Brasil.e-mail:ameliasilveira@gmail.com

\section{Leandro Petarnella}

Dr. em Adm. pela Univ. Nove de Julho. Prof. do Dep. de Ciências Gerenciais da Universidade Nove de Julho. São Paulo, SP. Brasil. e-mail: leandro_66@hotmail.com

\section{ABSTRACT}

This article is part of a research in progress which aims at defining a set of sustainability indicators that meets the specificities of a Higher Education Institution (HEI). The objective was to identify what is the responsibility of the HEls before sustainability and the sustainable development from the managers' insights. This is a qualitative research with case study design. The collection techniques used were bibliographical and documentary research and semi-structured interviews with ten managers of the institution. It was determined that managers understand sustainability broadly. The managers mention the importance of applying the concepts to management practices in order to be an example to other institutions and to contribute to the sustainable development of the region where it operates. The respondents cited several actions developed in the HEls. These results provide subsidies for the construction of a sustainability indicator system for monitoring and assessing the effectiveness of the actions developed.

Keywords: Sustainability. Higher Education. Sustainable development.

\section{RESUMO}

Este trabalho é um recorte de uma pesquisa em andamento que busca definir um conjunto de indicadores de sustentabilidade que atenda às especificidades de uma Instituição de Ensino Superior (IES). O objetivo foi identificar, no entendimento dos gestores, qual a responsabilidade da IES frente à sustentabilidade e ao desenvolvimento sustentável. Trata-se de pesquisa de abordagem qualitativa, com delineamento de estudo de caso. As técnicas de coleta foram a pesquisa bibliográfica e documental e a entrevista semiestruturada, com dez gestores da instituição. Os gestores indicam a importância da aplicação dos conceitos de sustentabilidade nas práticas de gestão para que sirvam de exemplo às demais instituições, e contribui para o desenvolvimento sustentável da região em que atuam. Foram relacionadas pelos respondentes inúmeras ações desenvolvidas na IES. Estes resultados oferecem subsídios para a construção de um sistema de indicadores de sustentabilidade que permite o acompanhamento e a avaliação da efetividade das ações desenvolvidas.

Palavras-chave: Sustentabilidade. Educação Superior. Desenvolvimento sustentável. 


\section{INTRODUÇÃO}

Factors such as growing environmental degradation, over-consumption and social inequalities have boosted the creation of events, documents and agreements, which aim to raise concerns in the minds of managers of public and private institutions and of the society about aspects related to sustainability and sustainable development. These factors have brought challenges to the organizations, and facing and solving them is established as a condition to their continuity within the new and emerging social paradigms brought by sustainability. Strictly speaking, it means that organizations need to adapt to this reality and should strive for constant improvement in their management practices, in order to evolve in a sustainable way, in other words, meeting "[...] the needs of the present without compromising the ability of future generations in meeting their own needs." (Comissão mundial sobre meio ambiente e desenvolvimento 1991, our translation).

The debate about this theme had its beginning back in the 70s. However, the universities in Brazil began to participate more actively in these discussions only after the middle of the 90s (Viegas and Cabral 2015). As a result, Higher Education Institutions (HEIs), as educational agents, have the mission of changing the social thought through their actors, what implies, in turn, that they must be example to the people and enterprises in their surroundings. In other words, they must work based on the sustainable development of the regions where they are located. In this regard, these organizations become a booster to the expected change, as the study developed by Viegas and Cabral (2015, p. 237, our translation) points out when stating that "[...] HEIs are at the forefront of knowledge construction and of sustainable values, as well as in the integration of these knowledge and values in their management models."

HEIs contribute to the sustainable development through their teaching, research, extension, and management practices. According to Madeira (2008), the sustainable university is the one that values the quality teaching, implements practices aiming at the improvement of the quality of academic life and is concerned about managing the use of natural resources. That is why, according to Silva et al. (2015, our translation), "[...] these organizations must integrate the sustainability principles and practices", since, according to the same authors, this attitude is important both in order to begin a process of raising awareness in the academic community and to help in the decision-making processes, planning and operations.

What was presented implies the understanding that the competence of these institutions goes beyond alerting about the economic, social, and environmental problems, showing need to create solutions and alternatives to these issues (Kramer 2000). Thus, once the managers' acting defines the success or failure in meeting these competences, studies that seek to understand how managers understand sustainability, and, more specifically in the scope of a HEI, which responsibilities they relate to it, are considered important and necessary, justifying the topic of this work.

For being a part of a research in progress, which aims at defining a set of sustainability indicators that meets the specificities of a Higher Education Institution, considering its internal and external context, this article sought to identify what is the responsibility of the HEIs before sustainability and the sustainable development from the managers' insights. For this purpose, from a bibliographical research, to provide a better approach to the theme, the managers' perceptions about the theme were identified and related to the sustainable actions developed by the institution. In order to achieve the objectives, a descriptive qualitative research was developed and it had the study performed in Universidade Federal da Fronteira Sul (UFFS) as focus. Bibliographical and documental research and semi-structured interviews with the managers were used as the collection techniques, and to analyze the results, the content analysis was used.

For the presentation of the referred research, this article was organized in five sections. Besides this introduction, as first section, the bibliographical review used as theoretical background is described in the second section. In the third one, the methodology employed to the accomplishment of this study is presented, so that, in the fourth section, the analysis of the results is reported. In the fifth and last section of this article, the final considerations of the study are revealed. 


\section{BIBLIOGRAPHICAL REVIEWS}

In order to support the purpose of this research, it is necessary to raise some of the main concepts and definitions about sustainability, sustainable development and higher education. This section is concerned about presenting this contextualization.

\subsection{Sustainability and Sustainable Development}

The growing concern and debate about themes as sustainability and sustainable development, according to Follows and Jobber (2010), may be result of the acknowledgment of the crisis in the environment. Since the 70s this theme has been discussed and it is getting better outlines from the report Our Common Future, or Brundtland Report, which defines sustainable development as "[...] the one that meets the needs of the present without compromising the ability of future generations in meeting their own needs." (Comissão mundial sobre meio ambiente e desenvolvimento 1991, p. 9, our translation). Strictly speaking, it is a kind of development which ensures the quality of life by keeping the environment preservation with the objective of ensuring the continuity of the external environment, as well as its own continuity (Van Bellen 2006).

Certainly, every crisis points out a paradigmatic change. The need to detach a secularly established thought, evidenced from the First Industrial Revolution, in order to understand the "development as freedom”, according to what Sen (2010) says, evokes social transformation beginning from the reduction of the non-freedoms, such as poverty, tyranny, few economic opportunities, social deprivation systems, negligence in the supply of public goods, intolerance and authoritarianism of oppressive systems. Because of this, in the expected paradigm, the term development is related to the removal of restrictions, which constrain people's choices and opportunities (Sen 2010). Lozano (2008) has the same thinking, for he sees sustainable development as an alternative to understand, fight and reduce economic inequalities, environmental deterioration and social problems.

If autonomy and conscious freedom, disconnected from the idea of exploitation and depriva- tion that dominated the modern rationality, are established as the expected paradigm, sustainable development, here in Sartori, Latrônico and Campos's (2014) view, may be understood as the way to get to sustainability; in other words, it is perceived as a process to achieve the objective, which, in this case, is sustainability. Therefore, if the two concepts are closely related, they are established as an only construct to the new expected social order.

In order to reach sustainability, Elkington (2001) proposes a model known as Triple Bottom Line (TBL). It has the aim of seeking the balance between economic efficiency, social equity and environmental preservation. It includes the environmental, economic and social pillars. The economic pillar encompasses the market, quality, cost, competitiveness (Araújo et al. 2006) and the distribution and efficient allocation of the natural resources (Van Bellen 2006). The environmental pillar is related to the environmental preservation. Araújo et al. (2006) affirm that the environmental sustainability includes clean technology, recycling, environmental impacts and eco-friendly products. According to Elkington (2001), the social pillar encompasses education, health and abilities; however, the author emphasizes the need to expand the understanding in relation to wealth generation and to the society's health.

From the intersections among the pillars, he discloses what is expected as social modus operandi. The intersection, for example, between the environmental and the social pillars, results in environmental justice, which is what is expected as possibility of social transformation. Another example is the eco-efficiency originated from the intersection between the economic and the environmental pillars. Ethic and socially responsible entities could, then, conduct their actions from the business ethic, which is originated from the intersection between the economic and the social pillars (Elkington 2001). It is important to highlight that this understanding is not unanimous, and Van Bellen's (2006) studies are an evidence of it; they include, for example, geographic sustainability, which can be reached through improvements of the distribution of human settlement and activities related to economy. Sachs' (1997) works also evoke another understanding, getting sustainability through the following aspects: social, economic, ecological, 
spatial, territorial, cultural, national policy, and international policy. The fact is that the conceptual breadth of what is expected from a new social order implies the necessity of discussing, disseminating and fomenting its implementation, evoking, again, one of the responsibilities of the educational institutions in their role of social transformation. Here, specifically related to the higher education.

\subsection{Sustainability and Higher Education}

Besides contributing to the sustainable development of the region where they are located, the Higher Education Institutions are among the responsible for disseminating the concept of sustainability, as well as fomenting its practices. They assume, according to Silva et al. (2015, p. 149), “[...] an essential responsibility in the preparation of new generations to a viable future, by using the reflection and by their basic research works." The HEIs can achieve these objectives by proposing extension actions, promoting the formation of aware citizens, and serving, through their practices, as a management model to be followed by the enterprises around them. According to Brandli et al. (2011), they can serve as model and example of sustainable development to the whole society, because the duties assigned to the HEIs include administrative and academic activities, which constitute the University's tripod, inter-relating teaching, research and extension.

If the purposes of the higher education, as cited in article 43 of the Law of Directives and Bases (LDB) (Lei n. 9394 1996, our translation), are focused on the commitment of "[...] stimulating the awareness of the problems of this world, in particular the national and the regional ones, providing specialized services to the community and establishing a reciprocal relationship with it", so, they receive the tasks of outlining and promoting what is expected from a society from the construction and consolidation of its actors' knowledge. And that is exactly the reason why the possibility of achieving sustainability is focused on the construction of knowledge from the academic sphere. Here, we agree with Reis (2007) in relation to the purposes of the HEIs: to offer benefits to the society, since their existence only makes sense due to their contribution to the development of the community and the society in which they operate.

The track taken by the university during the centuries of its existence has been divided into three important moments: teaching, research and extension. However, the dynamism it received with the introduction of the research, on its own, did not assure the integration with the environment. To fulfill the social gap, a third duty was planned: the university extension, created with the intent and expectation of achieving the social commitment of the university by means of a society's direct participation, supported by the results produced or developed for this purpose.

The extension actions are classified in program, project, course, event, and service provision. The university extension is the educative, cultural and scientific process that articulates teaching and research in such a way that they cannot be separated, and it enables transforming the relation between university and society (Fórum de Pró-reitores de Extensão das Universidades Públicas Brasileiras 2001). According to Costa, Almeida and Freitas (2010, p. 2), "In a basic relation, the university develops knowledge through teaching, which is improved by research and widespread by extension." Thus, considering the relevance of the theme sustainability in the higher education context, as well as the role of the Higher Education Institutions for sustainable development, it is highlighted that these themes must be a subject in higher education, considering teaching, research the extension, and disclosing, therefore, the value of their comprehension and their insertion in the management practices of these organizations.

From what was presented up to now, it is noticed that the HEIs cannot only be seen as responsible for the formation of professionals and as producers of knowledge, isolated from the rest of the society and of the problems involving them. Even because, according to what Peixoto (2003) reports, the main purpose of universities is the production and dissemination of knowledge, offering subsidies to solve social problems, in other words, from Chauís (2003) conception, it represents the structure and the functioning of the society as a whole.

Madeira (2008) understands that universities play the role of disseminating knowledge, they must act in the disclosure and promotion of sustainability; 
besides, they serve as model for other organizations. The Agenda 21 (Conferência das Nações Unidas sobre o Meio Ambiente e Desenvolvimento 1995), chapter 36, for example, cites the role of education, formal and informal, in assisting people change their attitude so that they are able to approach and evaluate the problems on sustainable development, addressing, inclusive, environmentalization. It is important to highlight that the term environmentalization has been used in Latin America for several decades to refer to the inclusion of environmental issues in higher education.

Environmentalization had its understanding expanded after the 90s, when it started to involve, besides environmental issues, sustainability in its social and economic aspects. However, it is emphasized that the most important thing is not the definition of terms, but the actions practiced by HEIs in favor of sustainability (Sáenz 2014), inasmuch as to include sustainability, knowledge about the subject, and participation and cooperation from the academic community are needed. Considering barriers such as the limitations in the organization's structure and the financial matter is also relevant (Evangelinos, Jones and Panoriou 2009).

Sorrentino and Biasoli (2014) believe there are two structuring axis of the socio-environmental sustainability in HEIs; the first one, related to utopias and values, refers to the questioning related to consumption. The second is related to the methodology, learning forms and the strategies to arouse the interest in the theme. The authors also indicate four procedures that aim at contributing to the dialogues in each HEI committed to the theme. The first step is the creation of a collective of professionals and collaborators who seek to find solutions towards environmentalization. The next step is to create a program devoted to the environmental education and sustainability, dedicated to policies related to teaching, research and extension. Beyond the formal procedures, the informal institutionalization is essential, stimulating the support to the environmental education in every space, inside and outside the institution. The last procedure is about the definition of a priority work which the institution will be committed to, in order to foster a collective educator aiming at cooperatively formulating and implementing a political pedagog- ical project that encourages demands to its teaching, research and extension activities.

In order to make the HEIs sustainable and to encourage the commitment to the sustainable development, several events and declarations arise over time; among the most significant ones, it is possible to mention:

a) Stockholm Declaration (1972): it was the first statement to reference sustainability in Higher Education, establishing (in $19^{\text {th }}$ principle) the necessity of the environmental education in every education level (United Nations Environment Programme 1972).

b) Talloires Declaration (1990): the first official statement made by university administrators; is a ten-point action plan for incorporating sustainability and environmental literacy in teaching, research, operations and outreach at colleges and universities (University Leaders for a Sustainable Future 1990).

c) Halifax Declaration (1991): resulting from a meeting attended by presidents of universities from several countries, it showed dissatisfaction with the degradation of the environment and the increase of poverty (United Nations Educational, Scientific and Cultural Organization 1991).

d) Agenda 21 (1992): it was elaborated in RIO-92, and in chapter 36, it addresses refocusing of education to the sustainable development, considering the role of educational and teacher training institution (Conferência das Nações Unidas sobre o Meio Ambiente e Desenvolvimento 1995).

e) Kyoto Declaration (1993): it has an appeal to the universities to a clearer interpretation of the sustainable development, following the principles and practices appropriate to the local, national and global contexts (International Organization of Universities 1993).

f) World Declaration on Higher Education for the Twenty-first Century (1998): elaborated by the United Nations Organization for Science, Education and Culture (UNESCO), it recommends greater cooperation among the HEIs, as well as greater inclusion of sustainability (United Nations Educational, Scientific and Cultural Organization 1998). 
Not only the mentioned initiatives, but uncountable other events and statements have sought the involvement of education institutions in the search for a sustainable world. In the first instance, the managers are responsible for meeting these commitments of the HEIs, it means they are responsible for the decision-making in these organizations. And it was for this reason and from the managers' perception on sustainability that the empirical research of this study was conducted, whose method is presented hereinafter.

\section{METHODOLOGY}

This study was developed at Universidade Federal da Fronteira Sul (UFFS), a National Institute for Higher Education (NIHE), situated in Southern Brazil. It is part of an ongoing research, whose purpose is to define a set of sustainability indicators that meets the specificities of a Higher Education Institution, considering its internal and external contexts. This step of the research sought to identify, from the perception of the managers, which is the responsibility of a Higher Education Institution before sustainability and sustainable development.

The study is characterized by the qualitative case study approach. The semi-structured interview with ten managers from the institution, allocated in the rectory, was the main data collection technique. The choice of this kind of interview has been made on account of its flexibility. The interviewees were defined by means of intentional sample, which occurs when the researcher uses his/her judgment to the selection, believing that the chosen elements represent the sample (Hair Jr. et al. 2005). In the same authors' insight, the main advantages of this kind of sample are "[...] its convenience, speed and low cost." (Hair Jr. et al. 2005, p. 247, our translation).

The bibliographical research and documental research techniques were also adopted in order to enable the approach and consciousness on the theme, identifying in literature the main constructs about sustainability, sustainable development and higher education, as well as evidences on the themes in the HEI under study.
The content analysis technique was used for data analysis (Bardin 2000). Sustainability, responsibility of HEIs, actions developed in the scope of the organizational unit (Secretariat, Pro-Rectory) and in the institutional scope, and actions oriented to the life quality on campus were defined as categories of analysis. Next section presents the data analysis.

\section{PRESENTATION AND ANALYSIS OF THE RESULTS}

Universidade Federal da Fronteira Sul is a public institution, classified as autarchy linked to the Ministry of Education. It was created by Law n. 12.029, of September $15^{\text {th }}, 2009$, and there was a strong involvement of several social movements to its project consolidation. Its implantation was part of the expansion policies of the Public Higher Education (Universidade Federal da Fronteira Sul 2015a), aiming to reach a portion of the population so far unassisted in relation to public higher education.

The Institution is directed to the attendance of approximately 3.800,000 inhabitants from the almost 400 municipalities that compose the mesoregion of the Large Border of Mercosul, which covers Northern Rio Grande do Sul, Western Santa Catarina and Southwestern Paraná (Universidade Federal da Fronteira Sul 2015a).

Headquartered in the city of Chapecó, its multicampus structure encompasses the three states of Southern Brazil, with six campuses situated in the cities of Chapecó, Passo Fundo, Erechim, Cerro Largo, Realeza and Laranjeiras do Sul. An amount of 608 professors, and 649 technical administrators, of which 259 are college graduates and 390 are high school graduates, compose the academic community, summing up a staff of 1,257 servants (Universidade Federal da Fronteira Sul 2015b). There are about 7,600 academic students in the Institution.

It is highlighted that among the ten managers interviewed, eight are male. The ages vary from 28 to 59 years. They are graduated in: pedagogy, agronomy, biological sciences, accounting sciences, sociology, administration and civil engineering. Three of them are doctors, three are masters, and two are Masters Students. Three of the managers interviewed have 
technical administrative positions, and seven are professors. Board 1 presents the interviewees' characterization, their graduation, position and function performed in the institution. Each interviewee's code name will be used to identify parts of the speeches mentioned hereinafter.

Board 1 The interviewees' characterization

\begin{tabular}{c|l|l}
\hline Enterviewee & \multicolumn{1}{|c}{ Graduation Course } & \multicolumn{1}{|c}{ Position/Function } \\
\hline E1 & Administration/Theology & Professor/Pro-rector \\
\hline E2 & Economy & Professor/ Pro-rector \\
\hline E3 & Social Sciences/Political Science & Professor/Pro-rector \\
\hline E4 & Accounting Sciences & Internal Auditor - Chief Auditor \\
\hline E5 & Biological Sciences & Professor/Special secretary \\
\hline E6 & Administration & Administrator/Pro-rector \\
\hline E7 & Pedagogy & Educator/ Institutional researcher \\
\hline E8 & Civil engineering & Civil engineer/Special secretary \\
\hline E9 & Accounting Sciences & Professor/Pro-rector \\
\hline E10 & Agronomy & Professor/Pro-rector \\
\hline
\end{tabular}

Source: the authors.

When the managers were asked about the concept of sustainability, most of them declared to see sustainability involving the social, environmental and economic pillars, according to what Elkington (2001), Araújo et al. (2006) and Van Bellen (2006) advocate.

E2 - $[\ldots]$ in the actions I practice in the Pro-rectory I try to make them sustainable, to have long, social, environmental and economic life. I cannot weigh one too much, because from the moment one of the three pillars [...] gets too strong [...] the other gets very week.

E3 - in short, sustainability involves, in first place, the environmental dimension, strictly. But we cannot perceive the environment only as nature, the environment is not only nature, it is nature and society. (verbal information, our translation).

They also approach the aspects that cover technological and cultural issues (Sachs 1997), in other words, they think on sustainability widely. According to E3, "The concept of sustainability, nowadays, adds a great set of themes, hope, expectations [...]" In the conception of E10, sustainability should be understood "[...] from the social point of view, the economic point of view, the environmental, structural, physical, chemical one [...]" (verbal information, our translation).
The managers evidenced the use of the term sustainable development as something that remains and does not preclude the use of the resources to the others (Van Bellen 2006). In the perception of E1, "[...] it is when a sector manages to survive in a balanced way and by itself, without depending on external resources or using other elements." In E2's conception, "[...] it is something that I can work over time." (verbal information, our translation).

It is evident that the managers see the sustainable development from the definition of "Our Common Future” Report (Comissão Mundial sobre Meio Ambiente e Desenvolvimento 1991).

E5 - I understand as something that maintains itself, something that remains with no need of new extractions, new uses of raw material or with the reduction of new extractions, new raw material.

E6 - [...] it a well-known term, which currently means to produce without endangering the development, without endangering the future generations' resources.

E7 - [...] it means to live, use the space, and restoring what I use. Not damaging, and allowing the existence of continuity, so that the others can use it as well.

E8 - [...] this is a very recent thing, not long ago, it had never been discussed. But I believe that it is to use the spaces thinking about the environment, in such a way that this same life 
quality can be left to future generations (verbal information, our translation).

It was evident from the managers' speeches that they see the responsibilities of the institutions concerning sustainability and the sustainable development. They highlight the roles assigned to the HEIs according to the literature: educational agents and are likely to be an example to the other organizations (Brandli et al. 2011; Madeira 2008). They also understand that the activity in these areas must include, besides management practices, teaching, research and extension.

E1 - First, as an education institution, it has an educational role in this area $[. .$.$] it also has a responsibility of being an$ example [...] it has the responsibility of taking that as a daily practice.

E2 - the university [...] is like a booster, it is the place where the conditions to that are created and it becomes an essential driving force.

E3 - [...] from the point of view of qualification, it implies, basically, three great movements inside the university. Besides the institution's commitment to the environmental management inside the university [...], in the education field, it is necessary to have instruction in that area. In research, you need to produce knowledge about the environmental area, and in extension $[\ldots]$ the relation with the community.

E7 - [...] to foment the ideas and practices so that they get consolidated in people's lives and around the place where they live. (verbal information, our translation).

When reflecting about the challenges, the main points raised are linked to cultural issues, consumerism (Sorrentino and Biasoli 2014), social inequalities (Sen 2010; Lozano 2008) and awareness. The difficulty in justifying the investments in sustainable projects was also reported. According to the respondents,

E9 - [...] to justify that a sustainable project costs than a non-sustainable one, in other words, it is very hard, very complex to measure sustainability to justify this gain.

E2 - [...] so, if you talk about the challenge of the sustainable development, the development will only happen when people embrace it.

E7 - There are people who need to go through campaigns, to be made aware [...] I think the university could have actions and campaigns [...], it is important to expand it to the society. E4 - I understand that in institutional scope, we should make a campaign for the awareness of the generated waste, waste separation, water, energy, and paper consumption.

E3 - [...] to manage the set of natural resources in such a way that it does not impact nature and build an economic model that allows income distribution [...] our great challenge is to deal with the logic of consumerism.
E3 - The first challenge is the environmental management, and the other three are to educate people, through teaching, through research and through extension.

E10 - [...] maybe we should have a report that allows us, for example, to evaluate what is UFFS' ecological footprint. (verbal information, our translation).

When they were asked about the actions developed in their organizational units related to sustainability, most of the interviewees cited awareness actions to the work teams. As E2 reveals when saying that "[...] the issue of the awareness of using the air conditioning, the waste separation, the use of draft paper, the use of glass mugs [...], they are simple actions." (verbal information, our translation).

Beyond the sustainable matter, according to E9, awareness is important because it can contribute to the cost reduction. The respondent affirms that the organizational unit where he works "[...] has worked in awareness, reminding people about the need to save electric power or other resources. But it always ends up having a moderate effect because of budget restriction, not for sustainable awareness." (verbal information, our translation).

Several actions are developed, even small ones, that contribute to sustainability, actions concerning the conscious consumption of water, paper, electric power and plastic cups.

E3 - Not leaving the lights on, not leaving the computer on, we print as little as possible.

E4 - We really seek the control of the use of water, energy power, even paper, printing both sides. The same way in relation to the waste generated.

E5 - [...] whenever possible, windows open, door open. And we nearly eliminated the disposable cups, we use our mugs. The air conditioning, if it is on, really, we keep the windows and the door closed (verbal information, our translation).

Even citing all those actions, the respondents did not mention more effective actions related to the awareness about them or to their efficiency. We believe that carrying out campaigns is of fundamental importance, campaigns that, besides the development, consider the monitoring and evaluation both of the participation and coverage of the awareness actions and of their effects on consumption.

It was also possible to verify the concern about the social pillar, which can be observed in E6's and 
E10's speeches when they approach the issues of transparency and social responsibility respectively. E6: "On the social side, for example, we try to show more transparency to public tenders [...] this matter of the vacancies made available to PNE and to black and brown people." E10: “[...] the social responsibility with the admission and permanence policies that are focused on the more socially vulnerable groups of the academic community." (verbal information, our translation).

This commitment with the permanence and the access as a way to fight social inequalities is explained on the Institutional Development Plan (IDP), which says that UFFS is proposed to be a "[...] University that establishes fighting mechanisms to the social and regional inequalities, including conditions of access and permanence in higher education, especially of the most excluded population from the countryside and the city." (Universidade Federal da Fronteira Sul 2012, p. 14, our translation).

Also according to the PDI, the institution is committed to keep permanent dialogue and interaction with the community. This interaction occurs mainly through the extension actions, according to E3: "[...] social projects involving small rural producers, women, Indians, schools, even the CTGs, even the part of the culture of Rio Grande do Sul [...] involvement with hydrographical basins, with the water management issue." (verbal information, our translation).

The respondents in general recognize the importance of the social actions to the inclusion and support to the regional development, what is evidenced in E1's perception, when reporting that they can be seen as "[...] opportunity of education to subjects that were previously excluded of higher education." (verbal information, our translation).

Besides the enforcement of the legislation, which requires the inclusion of the theme "sustainability" in teaching, specific courses related to this area were cited. According to E3, “[...] we have Masters in Environmental Science and Technology and in Agroecology. We have three courses of Environmental Engineering; these courses have graduated on average 40 students yearly."

Practices related to sustainable purchases, acquisition of low consumption equipment, purchase of family agricultural products, and inclusion of sustainable criteria in biddings have been cited.

[...] in all our biddings, sustainability criteria are in the auc-
tion notice. The fact that this bidding of University Restaurant
has now the thing that the enterprise which will attend must
have a portion of family agricultural products [...] we use
vehicles from outsourced fleets [...] because it is a much chea-
per transportation. (E2, verbal information, our translation).

For being a university under construction, numerous actions referring to the constructions, like solar orientation, use of solar panels for water heating, use of pavers for paving, reuse of rainwater, and sewage treatment were mentioned.

$[\ldots]$ we use the pavers, $[\ldots]$ we have a sewage treatment plant, reutilization of the rainwater. In the University Restaurant, we have hot water, all the water heating is by solar energy. The electrical system in these buildings follows the Procel stamp. All our buildings have solar orientation in order to consume less energy. (E8, verbal information, our translation).

Mobility and accessibility were also discussed, because the projects in the campuses have this concern. According to E8, "[...] in this project of the campus we favor the pedestrians, the automotive vehicles in general would always be out of the main center." (verbal information, our translation).

Regarding the environmental aspect, most of the actions mentioned are in attendance to the legislation. Among the activities mentioned, it is highlighted:

\footnotetext{
E2 - Sustainable Logistics Plan, participation on the Sustainability Challenge. An environmental management department was created.

E4 - [...] constitution of the Joint Selective Collection Committee.

E5 - [...] we are at the beginning of a work with the plan of laboratory waste management, selective collection of common residues, normative instruction to the residues and reagents station and the control of water and energy consumption. (verbal information, our translation).
}

The most quoted actions related to life quality on campus, involving professors, students and outsourced workers, were: work breaks campaigns, servants' week with speeches related to the awareness about health and life quality. They presented the concern with the labor rights of the outsourced servants, however, it is highlighted that these actions are 
often developed in compliance with legal demands. Referring to the professors, the concern about the permanence, health, psychological support, and others was reported. Generally, the institution seeks to develop projects that aim the improvement of life quality on campus, including mainly aspects related to the health of the academic community.

E1 - [...] we have culture activities, culture grant $[\ldots]$ in the case of the professors, the idea is psychological support and speeches.

E2 - [...] inspection of the outsourced contracts [...] IPO issues, safety equipment issues, receipt of the FGTS, of the transportation voucher and of the food tickets in time.

E7 - The management of UFFS meets the legislation, and the legislation is very strict [...] there is the accessibility matter [...] the matter of the University Restaurant itself [...] they develop campaigns with us and motivate us to exercise, and to be careful at work. There are periodic exams as well.

E10 - $[\ldots]$ there is an incentive system to small breaks throughout the working day.

E9 - there are health campaigns [...], but there is still a long way to go. This thing of having something really routine or long-term are always specific actions, there is not a constant affirmative action.

This initial phase of the study enabled to identify the perception of the managers about sustainability and sustainable development. Equally, what they understand as responsibility of a Higher Education Institution on this theme. It enabled the undertaking of a diagnosis about the actions that have been developed in the institutions, which will serve as a basis to the next step of the research, which aims at the creation of a preliminary system of sustainability indicators. Afterwards, the system will be adjusted and validated through the application of questionnaires and the creation of focal group.

\section{FINAL CONSIDERATIONS}

The case study enabled to observe that the managers interviewed have a broad understanding of sustainability, from many aspects: environmental, social, economic, cultural, technological, and others. They understand that a Higher Education Institution has an educational role and must include these matters in teaching, research and extension.

The managers expressed concern about the need to apply concepts of sustainability and sustainable development in their management practices, in order to serve as an example to other organizations. They understand that Higher Education Institutions can contribute to the sustainable development, either by their action in the development of aware citizens, the interaction with the community, through extension actions, or by means of the development of the research. When addressing the challenges faced by the HEIs in the attendance of their responsibilities before this theme, the relevance of cultural matters became evident, as well as the need of awareness of the academic community and of the general society.

It was also noticed that the managers see the need of going beyond the attendance of the current legislation, as an instrumental action. As the legislation is very wide and the HEIs integrate one of the most regulated segments of the public services, its attendance demands much energy and ends up becoming a guide of what to do. When thinking about sustainability and sustainable development in a HEI, the perspective must be substantive, in order to effectively incorporate sustainable practices of interacting with the environment and focusing on the human rights and on the demands of the society, adopting economically feasible management principles.

Countless actions developed were cited, however, most of the information arising from them are not systematized. These partial results offer subsides to the creation of a system of sustainability indicators that allows monitoring and assessing the effectiveness of the actions developed.

In conclusion, it is possible to affirm that the objective was achieved, the method was suited, and the results are initial, since the study belongs to a wider developing research. These results, however, do not invalidate what was presented here, and serve as a base to expand the theme of higher education and sustainability, from the understanding of the managers of a higher education institution of Santa Catarina. 


\section{REFERENCES}

ARAÚJO, G. C. de et al., 2006. Sustentabilidade empresarial: conceitos e indicadores. In Proceedings of the Congresso Virtual Brasileiro de Administração [viewed 17 December 2015]. Available from: http://www.convibra.com. br/2006/artigos/61_pdf.pdf

BARDIN, L., 2000. Análise de Conteúdo. Lisboa: Edições 70. ISBN 978-85-62938-04-7.

BORGES, J. M., 2013. A gestão universitária de projetos de extensão na perspectiva da gestão social: um estudo de caso do Centro Socioeconômico - CSE/ UFSC, no período de 2009 a 2012. 2013. (MS thesis) Universidade Federal de Santa Catarina - Programa de Pós-Graduação em Administração.

BRANDLI, L. L. et al., 2011. Indicadores de sustentabilidade ambiental da Universidade de Passo Fundo. Revista CIATEC - UPF [online]. vol. 3(1), 22-35 [viewed 20 October 2015]. Available from: http://seer. upf.br/index.php/ciatec/article/view/2188

CHAUÍ, M., 2003. A Universidade pública sob nova perspectiva. Revista Brasileira de Educação. (24), 6-14. ISSN: 1809-449X

COMISSÃO MUNDIAL SOBRE MEIO AMBIENTE E DESENVOLVIMENTO, 1991. Nosso futuro comum. $2^{a}$ ed. Rio de Janeiro: FGV.

COSTA, M. P., M. O. D. ALMEIDA, M. O. D. and T. S. FREITAS, 2010. Ensino, pesquisa e extensão: compromisso social das universidades [online] [viewed 17 December 2015]. Available from: http://www.uftm. edu.br/upload/ensino/tcc_teresinha.pdf

CONFERÊNCIA DAS NAÇÕES UNIDAS SOBRE O MEIO AMBIENTE E DESENVOLVIMENTO, 1995. Agenda 21 [online]. Brasília, DF: Câmara dos Deputados, Coordenação de Publicações. [viewed 14 October 2015]. Available from: http://portal.mec.gov. br/seb/arquivos/pdf/c36a21.pdf
ELKINGTON, J., 2001. A Teoria dos Três Pilares. In: J. ELKINGTON. Sustentabilidade: Canibais com garfo e faca. São Paulo: Makron Books. ISBN 978-85-7680-123-8

EVANGELINOS, K. I., N. JONES, and E. M. PANORIOU, 2009. Challenges and opportunities for sustainability in regional universities: a case study in Mytilene, Greece. Journal of Cleaner Production. vol. 17, 1154-1161. ISSN: 0959-6526

FOLLOWS, S. B. and D. JOBBER, 2000. Environmentally responsible purchase behavior: a test of consumer behavior. European Journal of Marketing. vol. 34(5-6), 723-746. ISSN: 0309-0566

FÓRUM DE PRÓ-REITORES DE EXTENSÃO DAS UNIVERSIDADES PÚBLICAS BRASILEIRAS and SESU/MEC, 2001. Plano Nacional de Extensão Universitária. Ilhéus: Editus.

HAIR J. F., Jr., et al., 2005. Fundamentos de Métodos de Pesquisa em Administração. Porto Alegre: Bookman.

INTERNATIONAL ORGANIZATION OF UNIVERSITIES, Kyoto Declaration on sustainable development [online] [viewed 10 February 2016]. Available from: http://archive.www.iau-aiu.net/sd/ sd_dkyoto.html

KRAEMER, M. E., 2003. Responsabilidade social: uma alavanca para a sustentabilidade. Revista Pensar Contábil. vol. 3(9). ISSN: 1519-0412.

LEI n. 9394. Estabelece as diretrizes e bases da Educação Nacional. Brasília, DF, 23 December 1996 [viewed 17 December 2015]. Available from: https:// www.planalto.gov.br/ccivil_03/Leis/L9394.htm

LOZANO, R., 2008. Envisioning sustainability three-dimensionally. Journal of Cleaner Production. vol. 16(17), 1838-1846. ISSN: 0959-6526. 
MADEIRA, A. C. F. D., 2008. Indicadores de sustentabilidade para instituições de ensino superior [online]. (MS thesis) Universidade do Porto - Faculdade de Engenharia [viewed 10 December 2015]. Available from: https://repositorio-aberto.up.pt/bitstream/10216/12228/1/Texto\%20integral.pdf

PEIXOTO, M. do C. de L., 2003. Gestão da qualidade da educação superior: avaliação e currículos. In: DOURADO, L. F., A. M. CATANI and J. F. OLIVEIRA orgs. Políticas e gestão da educação superior: transformações recentes e debates atuais. São Paulo: Xamã; Goiânia: Alternativa, pp. 207-217.

REIS, A. R., 2003. Responsabilidade social e ética das IES: Perspectiva Histórica e Conceitual. In: ROCHA, N. M. F. and A. S. SANTOS orgs. Educação, desenvolvimento humano e responsabilidade social: fazendo recortes na multidisplinaridade. Salvador: Fast Design, pp. 95-113.

SÁENZ, O., 2014. Panorama de la sustentabilidad en las universidades de América Latina y el Caribe. In: RUSCHEINSKY, A. et al. orgs. Ambientalização nas instituições de educação superior no Brasil: caminhos trilhados, desafios e possibilidades. São Carlos: EESC/USP.

SACHS, I., 1997. Desenvolvimento sustentável, bioindustrialização descentralizada e novas configurações rural-urbanas. Os casos da Índia e do Brasil. In: VIEIRA, P. F. and J. WEBER orgs. Gestão de recursos naturais renováveis e desenvolvimento: novos desafios para a pesquisa ambiental. São Paulo: Cortez.

\section{SARTORI, S., F. LATRÔNICO and L. M. S. CAMPOS,} 2014. Sustentabilidade e desenvolvimento sustentável: uma taxonomia no campo da literatura. Ambiente \& Sociedade. vol. 27(1), 1-22. ISSN: 1809-4422

SEN, A., 2010. Desenvolvimento como liberdade. São Paulo: Companhia das Letras. ISBN 978-85-359-1646-1

SILVA, A. A. N de M. et al., 2015. Gestão ambiental e universidade: o estudo de caso do programa Metodista sustentável. Desenvolvimento em questão. vol. 13(32). ISSN: 2237-6453
SORRENTINO, M. and S. BIASOLI, 2014. Ambientalização das instituições de educação superior: a educação ambiental contribuindo para a construção de sociedades sustentáveis. In: RUSCHEINSKY, A. et al. orgs. Ambientalização nas instituições de educação superior no Brasil: caminhos trilhados, desafios e possibilidades. São Carlos: EESC/USP.

UNESCO, 1998. World declaration on higher education for the twenty-first century: vision and action. Paris: UNESCO.

UNESCO, 2015. The Halifax Declaration [online] [viewed 10 October 2015]. Available from: http:// www.iisd.org/educate/declarat/halifax.htm

\section{UNITED NATIONS ENVIRONMENT} PROGRAMME, 2015. Declaration of the United Nations conference on the human environment [online] [viewed 10 May 2015]. Available from: http:// www.unep.org/Documents.Multilingual/Default. asp?documentid $=97$ \&articleid $=1503$

UNIVERSIDADE FEDERAL DA FRONTEIRA SUL, 2015a. A Instituição [online] [viewed 1 April 2015]. Available from: http://www.uffs.edu. $\mathrm{br} /$ index.php? option $=$ com_content $\& v i e w=$ article\&id=90\&Itemid $=822$

UNIVERSIDADE FEDERAL DA FRONTEIRA SUL, 2015b. Cargos vagos e ocupados [online] [viewed 10 May 2015]. Available from: http://www.uffs.edu. $\mathrm{br} /$ index.php? option $=$ com_content $\& v i e w=$ article\&id=611\&Itemid $=2229 \&$ site $=$ dgp

UNIVERSIDADE FEDERAL DA FRONTEIRA SUL, 2015c. Organograma [online] [viewed 13 May 2015]. Available from: http://www.uffs.edu. $\mathrm{br} /$ index.php? option $=$ com_content $\& v i e w=$ article\&id $=5122 \&$ Itemid $=2034$

UNIVERSIDADE FEDERAL DA FRONTEIRA SUL, 2015d. Plano de Desenvolvimento Institucional - PDI [online] [viewed 16 April 2015]. Available from: http://www.uffs.edu.br/images/proplan/PDI/Verso_ PDI_para_Consuni_-_30-08-2013.pdf 
UNIVERSITY LEADERS FOR A SUSTAINABLE FUTURE, 2015. Talloires Declaration [online] [viewed 15 May 2015]. Available from: http://www. ulsf.org/talloires_declaration.html

VAN BELLEN, H. M., 2006. Indicadores de sustentabilidade: uma análise comparativa. $2^{\mathrm{a}}$ ed. Rio de Janeiro: Ed. FGV. ISBN 978-85-225-1033-7.
VIEGAS, S. de F. da S. and E. R. CABRAL, 2015. Práticas de sustentabilidade em instituições de ensino superior: evidências de mudanças na gestão organizacional. Revista Gestão Universitária na América Latina - GUAL. vol. 8(1), 236-259 [online] [viewed 18 October 2015]. Available from: https://periodicos.ufsc.br/index.php/gual/article/ view/1983-4535.2015v8n1p236 